INTERNATIONAL JOURNAL OF RESEARCHES IN BIOSCIENCES, AGRICULTURE AND TECHNOLOGY (c) VISHWASHANTI MULTIPURPOSE SOCIETY (Global Peace Multipurpose So cie ty) R. No. MH-659/13(N) www.vmsindia.org

\title{
EFFECT OF PRETREATMENTS OF UDID SEEDS ON ITS GERMINABILITY
}

\section{Ashish Lambat ${ }^{1}$, Vipin Babhulkar ${ }^{2}$, Rajesh Gadewar $^{3}$, Sanjiv Charjan ${ }^{4}$, Prachi Lambat5 and Ramesh Parate ${ }^{6}$}

\author{
1,3 Sevada 1Mahila Mahavidyalaya and Research Academy, Nagpur (MS) \\ 2,4,6 Dr. PDKV's College of Agriculture Nagpur. \\ ${ }^{5}$ Shri Mathuradas Mohata Science College, Nagpur
}

Abstract:

Five genotypes Udid were sown during 2015. The seeds after harvesting, threshing and processing were evaluated for their hardseededness dormancy. The findings of the present study indicate that concentrated sulphuric acid, hot water, sand scarification and hot air oven methods are effective for reducing hardseededness in Udid. All the above mentioned treatments showed injuries effect to the seed embryo by increasing the dead seeds and abnormal seedlings except concentrated sulphuric acid treatment. In general concentrated sulphuric acid treatment for 60 seconds have been found most effective for breaking seeds coat dormancy and also significantly highest germination percentage compared to the above mentioned treatments under taken in the present inve stigation. Keyw ords: Udid, dormancy, hard seed coat, germination, seedling vigour, field emergence.

\section{Introduction:}

Seeds dormancy is defined as the state in which seeds are prevented from germination even under favorable conditions for germination. The impermeability of seed coat to water is typical example of exogenbility are known as hard seeds. This impermeability may be due to the presence of a cuticle and a well developed layer of palisade cells or both. Cutin deposits have been reported by Thronton (1968). The development of hard seeds has been reported to be influenced both by genotypic and environmental factors (Puri and Laudlaw, 1984)

Most of the legume crop plants produce hard seeds to varying percentages. Most workers have found this trait to be highly heritable. However, the available literature does not cle arly state the developmental stage in which the seed develops into hard seed. Hardseededness in Udid creates problems in testing for germinability under laboratory conditions. Due to this state of affair there is great problem under field condition in securing uniform germination and good crop stand for maximum crop production. The present study was undertaken to evaluate the methods to ove rcome hardseededness in Udid.

\section{Material and Methods:}

Five genotypes of Udid viz. T-9, TAU-1, TAU-2, TPU-4 AND PKV-Udid-15 we re used in the various phases of this study, produced in Kharif, 2015. Hard seeds which did not imbibe water were sorted out from the normal seeds which imbibe water. To evolve a quick method for breaking hardseededness in five genotypes of Udid, the hard seeds were subjected to concentrated sulphuric acid (for 60 and 90 seconds), hot water $\left(100^{\circ} \mathrm{C}\right.$ for 180 and 240 seconds), sand scarification $\left(100^{\circ} \mathrm{C}\right.$ for 15 and 30 seconds)
For germination test in laboratory, the germination medium used was rolled towels paper under controlled conditions (i.e. temperature at $25 \pm 2{ }^{\circ} \mathrm{C}$ constant and relative humidity $85 \%$ ), for acid treatment, the $100^{\circ} \mathrm{C}$ for 180 and 240 seconds) seeds were soaked in concentrated sulphuric acid for the specified duration with constant stirrings (Dharmalingam et al. 1973), Seeds were thoroughly washed in running water after the acid treatment and the germination was tested in quadruplicate with 100 seeds in each replication. The germination count was taken on the $8^{\text {th }}$ day and germination percentage was recorded on the basis of normal seedlings (ISTA,1985)

\section{Result and Discussion:}

Udid te sted for diffe re nt me thods of breaking the hardseededness are presented in Table 1. The overall comparisons of mean among and within genotypes and treatments for both normal seedling and hard seed percentage showed that concentrated suphuric acid for 60 seconds was the most effective treatment for reducing hard seeds content. It was followed by hot water for 180 seconds sand scarification for 480 seconds hot water 120 seconds, hot air oven 30 seconds, sand scarification 240 seconds, concentrated sulphuric acid of 30 seconds and hot air over 15 seconds. All the treatments showed injurious effect by increasing the abnormal seedling except concentrated sulphuric acid for 60 seconds. There is no ge rmination in control (untreated) seeds Duran and Tortosa (1985) has clearly explained the effect of concentrated sulphuric acid on seed coat of Sinapsisaruensis and conclude that it was the rapid dessiciation produced by concentrated sulphuric acid and not its 
hydrolytic capacity which seems to cause fragmentation of integuments and thus allowing the passage of water to the embryo. A similar mode of action can also be proposed for the shown as Udid genotypes to the treatment with sulphuric acid.

\section{Conclusion:}

The results obtained in the present investigation indicate that concentrated sulphuric acid treatment for 60 second has been found more effective for breaking hard seed coat dormancy in Udid. The result confirms the finding of Charjan and Tarar (1990), Sing and Tomer (1993) and Cherian et al. (2011).

Effective ness of concentrated sulphuric acid, hot water and hot air oven treatment for breaking hardseededness was also reported in related crops by Borikar et al. (1985), Radhakrishnan et al. (1989), Rana and Nautiyal. (1989), Tomer and Maguire.(1989), Verma and Singh.(1989), Charjan and Tarar. (1991), Singh and Tomer. (1993) and Cherian et al. (2011).

Table 1 Effect of different treatments on Germinability of Pigeon pea

\begin{tabular}{|c|c|c|c|c|c|c|c|c|c|c|c|c|c|c|c|c|}
\hline \multirow[t]{2}{*}{ S.N. } & \multirow[t]{2}{*}{ Treatments } & \multicolumn{3}{|c|}{ T-9 } & \multicolumn{3}{|c|}{ TAU-1 } & \multicolumn{3}{|c|}{ TAU-2 } & \multicolumn{3}{|c|}{ TPU-4 } & \multicolumn{3}{|c|}{ PKV-Udid-15 } \\
\hline & & $\mathrm{N}$ & $\mathrm{Ab}$ & $\mathrm{H}$ & $\mathrm{N}$ & $\mathrm{Ab}$ & $\mathrm{H}$ & $\mathrm{N}$ & $\mathrm{Ab}$ & $\mathrm{H}$ & $\mathrm{N}$ & $\mathrm{Ab}$ & $\mathrm{H}$ & $\mathrm{N}$ & $\mathrm{Ab}$ & $\mathrm{H}$ \\
\hline 1 & Con trol (Un trea ted hard see ds) & 0 & 0 & 100 & 0 & 0 & 100 & 0 & 0 & 100 & 0 & 0 & 100 & 0 & 0 & 10 \\
\hline \multirow{3}{*}{2} & Con $œ$ ntrated sulphuric acid & & & & & & & & & & & & & & & \\
\hline & (i) 30 secon ds & 82 & 2 & 16 & 87 & 3 & 10 & 85 & 7 & 10 & 82 & 6 & 12 & 85 & 5 & 10 \\
\hline & $\begin{array}{l}\text { (ii) } 60 \text { se conds } \\
\text { Hot wate } r \text { treatment }\left(100^{\circ} \mathrm{C}\right)\end{array}$ & 99 & 1 & 0 & 96 & 4 & 0 & 93 & 7 & 0 & 95 & 5 & 0 & 94 & 6 & 0 \\
\hline \multirow{2}{*}{3} & (i) 120 se conds & 83 & 2 & 15 & 80 & 3 & 17 & 82 & 3 & 15 & 80 & 2 & 18 & 79 & 3 & 18 \\
\hline & (ii) 180 secon ds & 90 & 3 & 7 & 92 & 3 & 5 & 90 & 5 & 5 & 91 & 5 & 4 & 92 & 5 & 3 \\
\hline \multirow{3}{*}{4} & Sand Scarification $(100 \circ \mathrm{C})$ & & & & & & & & & & & & & & & \\
\hline & (i) 240 se conds & 77 & 5 & 18 & 74 & 3 & 23 & 77 & 3 & 20 & 72 & 3 & 25 & 75 & 2 & 23 \\
\hline & (ii) 480 se con ds & 89 & 4 & 7 & 91 & 3 & 6 & 90 & 3 & 7 & 92 & 5 & 3 & 90 & 3 & 7 \\
\hline \multirow{3}{*}{5} & Hot air oven $\left(140^{\circ} \mathrm{C}\right)$ & & & & & & & & & & & & & & & \\
\hline & (i) 15 secon ds & 89 & 5 & 24 & 72 & 3 & 25 & 70 & 4 & 26 & 74 & 4 & 22 & 73 & 2 & 25 \\
\hline & (ii) 30 se conds & 86 & 6 & 8 & 89 & 5 & 6 & 87 & 4 & 9 & 89 & 3 & 8 & 88 & 4 & 8 \\
\hline
\end{tabular}

\section{Reference:}

Borikar, S.T ., Singh, A. R. and Katka de, J. L. 1985. Effect of pretreatment of greegram (Vigna radiate) seed with certain chemicals on its germination, seed Res. 13(1) : 192-194.

Charjan, S.K.U. and Tarar, J.L. 1990. Methods to overcome hardseededness in soybean (Glycine $\max \mathrm{L}$.) New Agriculturist 1(1): 71-74.

K. Cherian, A. Lambat, R.Gadwar, P. Bhandari, S. Charjan, P.Lambat. 2011. Post harvestdormany in Pigeon pea and their methods to overcome, In : Proceeding of the International Conference in Agricultural Engineering. Chon buri, Thailand C-45.

Dharmalingam, C. ,Madhavrao, S. and Sundara raj, D. 1973 Pregermination treatment of testing seeds (Tephrosiapurpures Pers.) to improve germination. Seeds Research. 1:58-62.

Duran.J.M. and Tortosa, M.E. 1985. The effect of me chanical and chemical scarification on germination of charlock (Sinapsisarvensis L. ) seeds, Seeds Science and Technology. 13: 155-163.

ISTA. 1985. In te mational rules for seeds testing. Seed Sci. and Technol. 13: 299-513
Puri, K.P. and Laudlow, A.S. 1984. The effect of temperature on components of seed yield and seed quality of hard red winter wheat from production field. J. App. Seed Production. 2: 18-23.

Radhakrishnana, J., Mahadevoppa, M. Joshi S. and Prasad, T.G. 1989. Dormancy studies in Cassia sericae seeds, Seeds Research. 17 (2) : 118-121

Rana. U., and Jautiyal, A.R. 1989. Coat imposed dormancy in Acacia famesiana seeds. Seeds Research. $17(2): 122$.

Singh, KJ. And Tomer, R.P.S. 1993. Studies on hard seeds in black - gram (Vignamumgo (L).He per, Seeds Research. Special Vol. 2 : 919 : 923.

Thornton, M.L, 1968. Seed dormancy in water melon.Proceedings Association official Seed Analysts. 58: $80-84$.

Tomer, RPS.And Magurie, J.D. 1989. Hard seed studies in alfalfa. Seeds Research. 17 (1) : 29-31.

Verma, O.P. and Singh, P.v. 1989. Methods to overcome hardseededness in Pige on pea. Seeds Research. 17 (2) : 197-198 